\title{
Ticks in the External Auditory Canal: A Common Situation in Rural Areas
}

\author{
Muhammet Recai Mazlumoglu* \\ Otorhinolaryngology Clinic, Hinis Sehit Yavuz Yurekseven State Hospital, Turkey
}

Submission: September 22, 2017; Published: January 25, 2018

*Corresponding author: Muhammet Recai Mazlumoglu, Otorhinolaryngology Clinic, Hinis Sehit Yavuz Yurekseven State Hospital \&

Administration Department, Palandoken State Hospital, Erzurum, Turkey, GSM: +90542435 5835; Tel: +904423273632; Fax: +904422351015;

Email: dr.mazlumoglu@gmail.com

\begin{abstract}
Objective: Foreign bodies in the external auditory canal generally occur in children, and are generally inert. Ticks constitute live foreign bodies. This is important, because ticks are vectors of many diseases, including Crimean Congo hemorrhagic fever. This article throw as light into a clinical problem seen frequently especially in rural population.

Material and Method: Patients living in rural areas diagnosed with ticks in the external auditory canal were retrospectively studied. Twentyone patients treated in otorhinolaryngology clinic in the Northeast Anatolian region of Turkey were examined in terms of demographic and seasonal features, diagnosis, treatment, and follow-up.
\end{abstract}

Results: The usual complaint was increasing ear pain. On parasitological examination, all ticks were Otobius megnini. No patient developed Crimean Congo hemorrhagic fever or any other illness.

Conclusion: Of living foreign bodies in the external auditory canal, ticks are common in our country (especially in rural areas). Although no Crimean Congo Hemorrhagic Fever have been noted, preventive measures are required.

Keywords: Tick; External auditory canal; Rural area; Crimean Congo Hemorrhagic Fever

\section{Introduction}

Foreign bodies in the external auditory canal (FBEAC) are frequently encountered in otolaryngology outpatient clinics and emergency departments, generally in children under 6 years of age. The most common foreign bodies are fruit nuclei, nuts, toys, beads, and (sometimes) living foreign bodies [1-3].

Ticks are obligatory blood-sucking arthropods and more than 900 species are known. Approximately 46 species are found in Turkey [4,5]. Such ectoparasites transmit typhus, Q fever, tularemia, Lyme disease, and Crimean Congo Hemorrhagic Fever (CCHF); the latter causes high-level human mortality [6-8].

\section{Materials and Methods}

For ethical consideration, application was made to local Education and Research Hospital Ethics Committee. The Ethics Committee approved the admission on 5 January 2016 with decision number 2016/1-2. In addition, informed consent was obtained from all the patients included in the study.

Between May 2014 and May 2016, 21 patients diagnosed with ticks in the EAC at the otorhinolaryngology clinic were retrospectively evaluated. Patient age, gender, occupation, area of residence, complaints, examination findings, treatment, and follow-up were recorded.

When ticks in the EAC were first identified, medical staff donned personal protective equipment (masks, glasses, gloves, and aprons) and the ticks were removed via autendoscopy using alligator forceps or curettes. Each tick was placed in a bottle and labeled. The EAC was washed with ciprofloxacin. Patients were then evaluated in terms of fever, headache, widespread body pain, arthralgia, malaise, diarrhea, and bleeding; and a complete blood count was performed. The patients were then told of the findings and followed-up for 7 days. This follow-up was done especially to exclude the CCHF. The ticks were examined parasitologically. The statistical analyses were performed using SPSS 20 (IBM, Armonk, NY, USA).

\section{Results}

Two of the 21 patients were male and 19 female. All patients (average age of 42.3 years; range 21 to 69 years) were engaged in animal husbandry (especially milking) in rural areas (Table 1). Most patients visited in spring and summer. The complaints were ear fullness, pain, hearing loss, and a sense of motion in 
the ear. Ten ticks were in the right ear and 11 in the left ear. One patient had three ticks in the same ear. All ticks were in the inner one-third of the EAC (Figure 1).

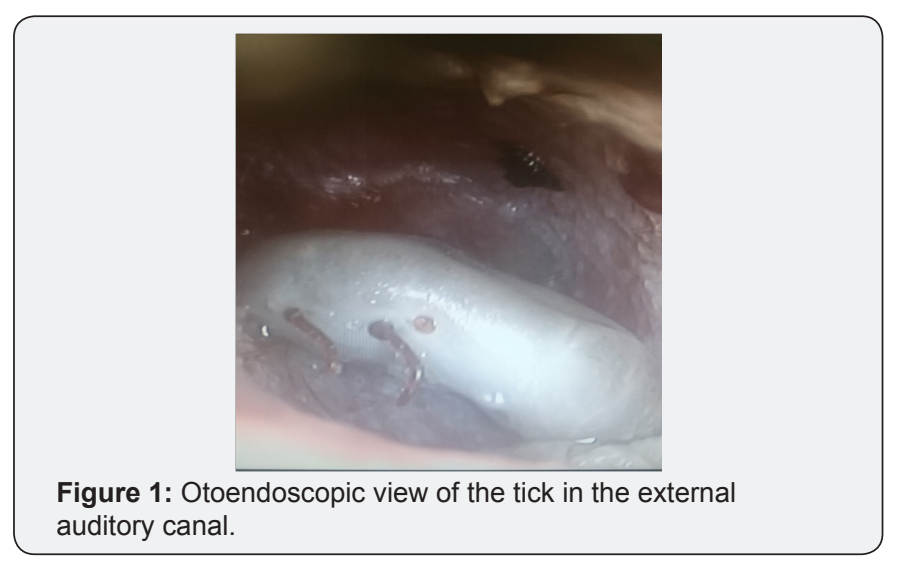

Table 1: Demographic characteristics of patients and seasonal frequency.

\begin{tabular}{|c|c|}
\hline & Number (n) \\
\hline Gender & 19 \\
\hline Female & 2 \\
\hline Male & \\
\hline Season & 9 \\
\hline Spring & 10 \\
\hline Summer & 2 \\
\hline Autumn & - \\
\hline Winter & \\
\hline Occupation & 21 \\
\hline Animal husbandry & \\
\hline
\end{tabular}

All of the patients were involved in animal husbandry and most presented in spring and summer.

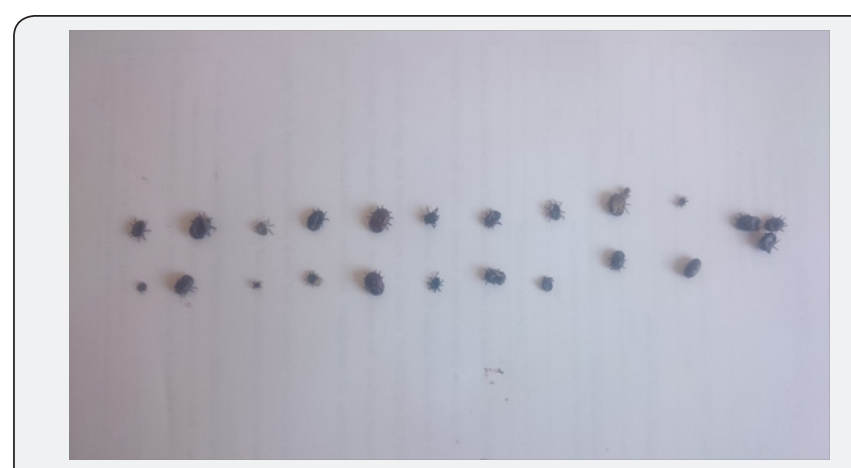

Figure 2: The ticks removed from the external auditory canal.

The ticks were removed under local anesthesia; we first attempted to catch them as they moved. If this was not possible, we broke the grip using a curette and then removed the tick. Parasitological examination revealed that all ticks were Otobius Megnini (Figure 2). On full blood counts, all patients were normal and no symptoms were observed to the end of the 7-day followup.

\section{Discussion}

Ticks are obligatory blood-sucking arthropods distributed worldwide and transmit many viral, bacterial, and parasitic infections to humans [8]. Ticks are divided into two main groups, the Ixodidae (which are stiff) and the Argasidae (which are soft). Approximately $80 \%$ of all ticks are stiff and the rest soft. Soft ticks are divided into four groups: Argas, Carios, Ornithodoros, and Otobius [5]. The ear tick is Otobius Megnini [9]. All ticks of the present study were of this species, as expected.

Typhus, Q fever, tularemia, lyme disease, and CCHF are ticktransmitted diseases; CCHF causes high-level human mortality. Fortunately, no case of CCHF transmitted by a tick in the EAC has yet been reported. Ticks can produce toxins causing irritation, facial paralysis, and allergies [10].

Of the various FBEAC, ticks are rare $[9,11]$. However, in some studies (especially that of Naik et al. [10]) ticks were not infrequent in the EAC; geographical and developmental features of the regions where studies are conducted are in play [5]. The risk of tick contact increases for those engaged in agriculture and animal husbandry; in spring and summer; and when picnicking [6]. As in other reports, all of our patients were involved in animal husbandry and most presented in spring and summer.

Patients with EAC ticks often complain of pain. Other complaints include fullness, hearing loss, tinnitus, and the sense of a moving object [9-11]. Pain can be very severe, depending on the size and location of the tick in the EAC [10]. The most common symptom in our present study was increasing pain as the tick grew over time by sucking blood.

General anesthesia may be required during treatment; FBEAC are often seen in children. Additionally, some reports have stated that general anesthesia may be required for tick removal [10]. However, as ticks are usually found in adults, removal under local anesthesia is generally possible $[3,5,10]$. Alligator forceps and ear curettes can be used to this end. If alligator forceps are employed, they should grip hard rather than soft tick tissue because, if soft tissue is gripped, the tick's contents may drain into the EAC. After tick removal, the EAC should be washed with an antibiotic solution to prevent secondary infection. The patient should be told about the risk of infectious diease; and followup scheduled. As mentioned previously, this study consists of patients only living in the rural area where our hospital is located. And all of the patients are adults. These seem to be the shortcomings of the study.

Ticks in the EAC are common in rural areas, especially in those who work in agriculture and with livestock. Although no patient in the literature has yet developed CCHF, it is necessary to exclude this disease and take protective measures. In addition, patients should be told that ticks can enter the EAC during milking.

\section{References}

1. Fritz S, Kelen G, Siverston KT (1987) Foreign bodies of the external auditory canal. Emerg Med Clin North Am 5(2): 183-191.

2. Erpek MG, Yorgancıoğlu A, Çelik $P$ (2002) Kulak burun boğaz hastalıkları ve baş boyun cerrahisi. Baskı, İstanbul: Turgut Yayıncılık pp. 985-995. 
3. Thompson SK, Wein RO, Dutcher PO (2003) External auditory canal foreign body removal: Management practices and outcomes. Laryngoscope 113(11): 1912-1915.

4. Horak IG, Camicas JL, Keirans JE (2002) The Argasidae, Ixodidae and Nuttalliellidae (Acari: Ixodida) a world list of valid tick names. Exp Appl Acarol 28(1-4): 27-54.

5. Gokdogan O, Cakabay T, Baran H, Karabulut B, Tasdemir C, et al. (2016) Otoacariasis: demographic and clinical outcomes of patients with ticks in the ear canal. Braz J Ototrhinolaryngol 82(4): 416-421.

6. Ergönül Ö, Çelikbaş A, Dokuzoğuz B, Eren Ş, Baykam N, et al. (2004) Characteristics of patients with Crimean-Congo haemorrhagic fever in arecent outbreak in Turkey and impact of oral ribavirin therapy. Clin Infect Dis 39(2): 284-287.

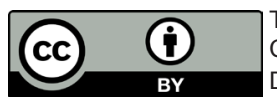

This work is licensed under Creative Commons Attribution 4.0 Licens

DOI: $10.19080 / J H N S S .2018 .02 .555581$
7. Le Due JW (1989) Epidemiology of hemorrhagic fever viruses. Rev Infect Dis 11 Suppl 4: S730-S735.

8. Keleş E, Karlıdağ T, Ișık Ö, Saki CE (2010) Dış Kulak Kanalında Kene: Olgu Sunumu. Firat Tip Dergisi 15(2): 110-112.

9. Lindström A, Lindström J (2017) First report of spinose ear tick, Otobius megnini (Acari, Argasidae), in Sweden. Exp Appl Acarol 72(2): 179-181.

10. Naik SM, Appaji M, Ravishankar S, Goutham MK, Annapurna SM, et al. (2013) Human otoacariasis: a common outbreak in rubber growing belt of Karnataka. Otolaryngology Online J 3(2): 16-24.

11. Alazzawi S, Omar R, Raman R (2016) The tick Ixodida: an unusual foreign body in the ear. Trop Doct 46(1): 62-63.

\section{Your next submission with Juniper Publishers will reach you the below assets}

- Quality Editorial service

- Swift Peer Review

- Reprints availability

- E-prints Service

- Manuscript Podcast for convenient understanding

- Global attainment for your research

- Manuscript accessibility in different formats

( Pdf, E-pub, Full Text, Audio)

- Unceasing customer service

Track the below URL for one-step submission https://juniperpublishers.com/online-submission.php 